\title{
Grammatical Errors in Nigerian English Language Pronunciation Problems Among Students: Psychological Implications and Management
}

\author{
B. C. Chigbu ${ }^{1}$, Janet Ngozi Igbo ${ }^{1}$, Fidelia N. Obayi ${ }^{1}$, V. C. Onu ${ }^{1}$, E. C. Ndukwu ${ }^{1} \&$ D. Ojonugwa Solomon ${ }^{1}$ \\ ${ }^{1}$ Department of Educational Foundations, University of Nigeria, Nsukka, Nigeria \\ Correspondence: Janet Ngozi Igbo, Department of Educational Foundations, University of Nigeria, Nsukka, \\ Nigeria. E-mail: janetigbo@yahoo.com
}

\author{
Received: April 17, $2020 \quad$ Accepted: August 20, $2020 \quad$ Online Published: September 7, 2020 \\ doi:10.5539/ijel.v10n6p162 URL: https://doi.org/10.5539/ijel.v10n6p162
}

\begin{abstract}
This study was designed to identify some English grammar pronunciation problems and how the problems can be managed. The population consists of all the first-year students in the University of Nigeria, Nsukka in Enugu State of Nigeria. Nine hundred and ninety-nine (999) students from four departments were sampled using simple random sampling technique. Three research questions and one null hypothesis were generated to guide the study. Mean and standard deviation were used to answer the three research questions while t-test statistic was used to test the null hypothesis. The results revealed that consonant and vowel phonemes, syllabic consonants, consonant cluster, unstressed vowels and stress timing are the aspects of pronunciation that are considered problematic among some first-year students. It also revealed that gender does not play a functional role on pronunciation problems among these first year students in the learning of English Grammar, and that teachers' emphasis on the problematic area of pronunciation, constant practice, teachers' knowledge of Oral English, building of language laboratories, teachers' use of compact disks and tapes on pronunciation, students access to compact disks and tapes on pronunciation dictionaries are the management strategies that can be used to improve pronunciation in English language.
\end{abstract}

Keywords: learning disability, pronunciation problems, grammatical errors, gender

\section{Introduction}

Language is a means of communication and this is acquired with appropriate pronunciation. Pronunciation is one of the most important aspects of English language. It is one of the problematic areas in the learning of the English language grammar. One of the reasons why pronunciation problems seem pervasive is that in the past, the emphasis of the English language study was on structure and syntax. Later, the emphasis shifted to the spoken English. As a result of the neglect of pronunciation over the years, many Nigerians, particularly university students, who offer two general studies courses in the use of English language in the university, of Nigeria, Nsukka, are known to be deep into wrong pronunciation of English words, wrong use of the syllables, and stress and intonation. Pronunciation problems such as consonant and vowel phonemes, syllabic consonants, consonant and unstressed vowels are prominent in the speeches of many Nigerians, the educated ones included. This has, to a large extent, influenced the learning of grammar along with mispronunciation. Mispronouncing a word may affect how it is read in a connected speech, perceived by the listener, written and understood. Mbah (2004) carried out a research on the problems associated with the learning of Oral English in senior secondary school students who are about to mainstream to the university. The purpose of study was to explore the kind of problems students encounter in the learning of Oral English. The findings showed that the students perceived the 'mother tongue' interference as a major source of their problems in the learning of Oral English. A good knowledge of the English language sound system will make the learner change or adapt to the correct pronunciation processes

\subsection{The Purpose of the Study}

This study is directed towards identifying the problematic areas of pronunciation on the learning of English language grammar among students in the Faculty of Education University of Nigeria, Nsukka, for purpose of finding ways of managing the problems. Specifically, the study identified the forms of pronunciation problems in 
the learning of English grammar among first year students offering the use of English language as a course, the influence of gender on the pronunciation problems on the respondents (students) in the learning of English grammar; and the management strategies that can be used to improve pronunciation problems among students.

\subsection{The Scope}

The content scope encompasses the pronunciation aspect of English Language. This was restricted to the oral skills. The study examined the segmental and the suprasegmental features which have to do with branch of phonetics (vowels and consonants) and phonetics (syllable, the stress and the intonation) respectively. The geographical scope covered first year students in the Faculty of Education, University of Nigeria, Nsukka who are between the ages of 18 and 20 years.

\subsection{Research Questions}

What are the forms of pronunciation problem in the learning of English grammar among first year university students? What is the influence of gender on the pronunciation problems among students? What management strategies can be adopted to control pronunciation problems among first year university students?

\subsection{Hypothesis $\mathrm{HO}_{1}$}

The hypothesis of the study is that: Gender has no significant influence on the pronunciation problems of first year university students in the learning of English grammar.

\subsection{Significance of the Study}

Significantly, knowing the problematic areas of pronunciation and making efforts to correct such errors, the students will be in a better position to overcome those problematic areas. This will enhance their overall performance in other aspects of the English language. Teachers will find this article useful, by getting to know the problematic areas of pronunciation they will be in a position to manage the problems for students' better understanding. It will help the teachers to update their teaching skills which will equally increase the students learning ability. Above all, this study will act as a reference point to other researchers who may wish to write on similar articles. In line with this Eyisi (2002) stated that if English language is not correct, then what is said is not what is meant; if what is said is not what is meant, then what ought to be done remains undone.

\subsection{Conceptual Framework}

For Myer (2002), pronunciation is what lies heavily on the pronunciation of phonemes. Phonemes are the simplest sound elements that distinguish one word from another which is referred to as segments that produces a continuous stream of sound when people speak (Roach, 2003). Phonemes precisely indicate the sound characteristics of the language in question. For example, the English word: 'at' contains two phonemes, the word 'mat' three, while 'mast' contains four. Very frequently, however, the study of English words and sentences start from the phonemes. Also, the word 'man' is pronounced with a first segment in a second segment and a third segment. These segments or continuous streams of sound are referred to as phonemes.

The sound system of English language is made up of two main features, the segmental and the supra segmental features (Onuigbo, 2006). The segmental features are simply the vowels and the consonants while the supra segmental features are stress, rhythm, and intonation. Therefore, the learning of English grammar cannot be efficient without the effective knowledge of pronunciation and its problematic areas. The problematic areas of pronunciation may be influenced by gender. Gender is a form of social differentiation; it is a socio-cultural distinction between males and females (Hughes, Kroehler, \& Zanden, 1999). It refers to the differences in sex of human being as to whether one is masculine or feminine. It is the status of beings male or female.

Mangal (2009), noted that poor pronunciation and interpretation problems usually referred to as dyslexia, whereby, the student lacks the ability to tell the difference between sounds. Adina, Ladipo and Abosi (1991) stated that learners may experience expressive language pronunciation disability which is referred to as 'Aphasia'. The implication is that some consonant and vowel phonemes pose some difficulty in pronunciation to the learners. For example, the dental sounds $/ \theta /$ and $/ \partial /$ which are common in English are relatively rare in Nigerian indigenous languages. Onuigbo (2006) states that learners of English in Nigeria find it difficult to pronounce $/ \theta /$ properly and usually experience some problems in pronouncing $/ \partial /$ with $/ \mathrm{t} /$ sound and a $/ \partial /$ sound for a $/ \mathrm{d} /$ sound. Instead of pronouncing them $/ \theta \mathrm{i}: \mathrm{m} /$, learners will pronounce $/ \mathrm{ti}: \mathrm{m} /$ and instead of pronouncing father /fa: $\partial /$, learners will pronounce /fa:d/. The same thing is applicable in /s/ especially when it has to do with the pronunciation of plural makers.

Again, such vowel phonemes as /æo/ "do not occur in the Nigerian languages. Learners of English in Nigeria sometimes have trouble in articulating the vowel properly". For the sound $/ \wedge /$, some learners substitute it with $/ \alpha /$. 
They pronounce $/ \mathrm{s} \alpha \mathrm{n} /$ instead of $/ \mathrm{s} \wedge \mathrm{n} /$ and $/ \mathrm{bl} \alpha \mathrm{d} /$ instead of $/ \mathrm{bl} \wedge \mathrm{d} /$. Consonant and vowel phonemes are among the problematic areas of pronunciation in the learning of English grammar. For Eyisi (2002), some syllables do not contain vowels as their peak of prominence. Rather, such syllables carry with them a special type of consonant known as syllabic consonant. For instance, cattle, garden and cotton are words that contain syllabic consonant. They are all two-syllabic word: $\mathrm{ca}+\mathrm{ttle}$, gar + den and cot + ton.

Cattel - cat+tle/køel/

Garden - gar+den/ga:dn/

Cotton - cot+ton $+/ \mathrm{k} \alpha \mathrm{tn} /$

Looking at the transcription of the words, one can see that the vowels in the second syllables of the words are replaced by consonants $/ 1 /$ and $/ \mathrm{n} /$. The consonants function as the peak of the syllables instead of vowels. Consonants that behave in this way are called 'syllabic consonants'. Onuigbo (2006) states that syllabic consonant is a consonant that functions as the nucleus of the syllable instead of a vowel. Syllabic consonants are also among the problematic areas of pronunciation in the leaning of English grammar particularly among children and illiterate adult learners. Again, consonant cluster is another area of pronunciation that poses some difficulty to learners of English grammar. The major cause of this problem is that these complex structures are not existent in the learners' indigenous languages. Ezurike-Nwadigbo (2008) states that consonant cluster is the coming together of more than one consonant sound in a word. The cluster of consonants without the intervening vowels can be found at the initial position. For Anyackonkeya and Izuagha (1999), consonant cluster poses problems to learners of English language. For examples, many learners of English as a second language may find it difficult to pronounce such words with cluster of consonants as "spirit", "choir" or "insight". Onuigbo (2006) states that such difficulty results in the cluster of two or three consonants without an intervening vowel.

Unstressed vowel is also among the problematic areas of pronunciation. There is a vowel that is not always stressed. Mbah and Mbah (2000) call the unstressed vowel the weakest vowel of the English language. Such a case presents learners of English with some difficulties. For example, "from" has a short " $\alpha$ " sound when it is stressed and the schwa sound $/ \partial /$ when it is unstressed. Sometimes, the learners tend to over pronounce these unstressed vowels, giving their speech an unnatural rhythm. A learner of English may pronounce husband $/ \mathrm{h} \wedge \mathrm{zb} \partial \mathrm{nd} / \mathrm{as} / \mathrm{h} \wedge \mathrm{zb} \propto \mathrm{d} /$ and above $/ \curvearrowright \mathrm{b} / \wedge \mathrm{v} /$ as $/ \curvearrowright \mathrm{ob} \wedge \mathrm{v} /$. That is why Roach (2003) stated that the unstressed vowel is generally described as lax, that is, not articulated with much energy. The unstressed vowel poses great difficulty of pronunciation to the learners of English. This, thus, poses a challenge to teachers and facilitators on how to manage such learners.

Adesina (1990) sees management as the organization and mobilization of all human and material resources in a particular system for the achievement of identified objectives in the system. This implies that the aim of management is to attain particular aims and objectives. Pronunciation problems can be managed in different ways. In the first place, teachers' emphasis on the problematic areas of pronunciation is among the management strategies. Eyisi (2002), states that there is the need to drill students seriously in the problematic areas of pronunciation. Teachers devote their time in teaching students these problematic areas. Baldeh (1990) states that teaching must be systematic, progressing from one point to another in a regular fashion. Above all, we must teach the structural patterns in orderly way. For this to be effective insight into grammar in the sense of structure is essential, because it is central to the whole process. Anyachonkeya and Izuagba (1999), state that teachers of Oral English are to teach learners the problematic areas. The knowledge of these areas enables the students to appreciate how the vowels and consonants are combined into various units in speeches as well as in writing.

It is also believed that constant practice on the part of the learners minimizes pronunciation problems. Eyisi (2002) states that accelerated improvement in the pronunciation of English words are dependent on effective listening and continual practice. Enete (2008) conducted a study on the strategies for teaching Oral English in senior secondary schools. The purpose of the study was to find out the strategies for effective teaching of Oral English in senior secondary schools in Nsukka Urban Area of Enugu State. The findings revealed that male and female Oral English teachers in the 12 secondary schools in Nsukka Urban are of the opinion that English teachers in Nsukka use appropriate Oral English strategies. Retention is high when there is constant practice. Learners are to practice those difficult areas constantly in order to be accustomed to them. Learners' constant practice of pronunciation problems is an aid in managing pronunciation problems. Besides, proficiency on the part of Oral English teachers also minimizes pronunciation problems in the learning of English grammar.

Building of phonetic laboratories in educational institutions at all levels, including in adult learning centers, is another management strategy that is used to minimize the problematic areas of pronunciation. This provides the students with enough opportunity for experimentation. Roach (2003) states that experimental phonetics has been 
an important part of phonetics for most of the twentieth century, and experimental work in phonetics laboratories have produced many important discoveries about how speech is produced and perceived. The phonetic laboratories provide a forum for thorough research on pronunciation. Listening to pronunciation guides on tapes also motivates learners and help to minimize the problematic areas of pronunciation. Anyachonkeya and Izuagba (1999) stated that the major aspect of the English language study is the spoken English and no measure of success can be achieved when we are ignorant of the English language sound system. According to Boss and Vaughan (2002) conversation among facilitators and learners should be applied to promote English language development.

\section{Research Method}

The researchers used descriptive survey research design in carrying out the study. Descriptive survey research is one in which a group of people is studied by collecting and analyzing data from only a few people or items considered to be representative of the entire group (Nworgu, 2015). The study was conducted in the University of Nigeria, Nsukka, in Enugu State of Nigeria. The population of the study comprises all the first-year students. From the available statistics, as at the time of this study, there were three thousand one hundred and eighty-two $(3,182)$ first year students in the fourteen (14) faculties of the University. The researchers randomly selected four out of the seven departments that make up the faculty of Education. The sample for the study was nine hundred and ninety-nine respondents. Instrument for data collection was a structured questionnaire, entitled identification and management of pronunciation problems on the learning of English Grammar. The questionnaire is made up of two sections. They are the problematic areas of pronunciation and the management strategies of pronunciation problems. The items were designed to elicit relevant information from the respondents. The questionnaire is a four-point rating scale of strongly agree (4), agree (3), disagree (2), strongly disagree (1). The instrument was validated by three experts, one each from Educational Foundations, Adult Education and Measurement and evaluation, all in the University of Nigeria Nsukka. In determining the reliability of the instrument, a trial testing was carried. The internal consistency was determined using Cronbach Alpha procedure, which yielded coefficient values of $0.94,0.84,0.89$ and 0.89 as the overall reliability. From the results stated, the indication is that the instrument was reliable.

Copies of the questionnaire were distributed to the respondents by the researchers with the help of two research assistants who were briefed by the researchers on how to administer the questionnaire in order to enhance quick return of the copies of the questionnaire. Personal contact approach was adopted in the distribution and collection of the completed questionnaire from the students who constituted the subjects for this study.

Data addressing the research questions were analyzed using mean and standard deviation, while t-test statistics was used to test the null-hypothesis. The criterion mean point is 2.50 . The implication is that any item less than 2.5 is rejected and above 2.5 is accepted. 


\section{Results}

Table 1. Mean ratings of the response on the aspects of pronunciation that are considered problematic among the respondents

\begin{tabular}{|c|c|c|c|c|c|}
\hline $\mathbf{S} / \mathbf{N}$ & Statement & $\mathbf{N}$ & $\mathbf{X}$ & SD & Decision \\
\hline 1 & $\begin{array}{l}\text { Students mispronounce consonant phoneme letter } / \theta / \text { for } / t / \text {. Examples: Thank for tank, thick } \\
\text { for tic }\end{array}$ & 999 & 3.80 & 0.39 & Agree \\
\hline 2 & $\begin{array}{l}\text { Students mispronounce consonant phoneme letter } / \mathrm{t} / \text { for } / \mathrm{n} / \text {. Example: learning for nearing, } \\
\text { land for nand, law for naw }\end{array}$ & 999 & 3.40 & 0.60 & Agree \\
\hline 3 & $\begin{array}{l}\text { Students mispronounce vowel phoneme letter } / 3 \text { : for } /: / \text { Examples: burn for born, turn for torn, } \\
\text { curd for cord, word for ward. }\end{array}$ & 999 & 3.33 & 0.78 & Agree \\
\hline 4 & $\begin{array}{l}\text { Students also mispronounce the vowel phoneme } / \wedge / \text { for } / \alpha / \text {. Examples: hut for hut, cut for cot, } \\
\text { cup for cop. }\end{array}$ & 999 & 3.34 & 0.86 & Agree \\
\hline 5 & $\begin{array}{l}\text { Students often use a vowel with a syllabic consonant /1/ instead of kettle /ketl/, pronounce } \\
\text { /kettle/, and instead of bottle /batl/ they pronounce /batle/. }\end{array}$ & 999 & 2.79 & 0.90 & Agree \\
\hline 6 & $\begin{array}{l}\text { Students use a vowel with a syllabic consonant /n/. Instead of garden /ga:dn/ they pronounce } \\
\text { /ga:din/ and instead of bitten /bitn/ they pronounce /bitin/. }\end{array}$ & 999 & 3.33 & 0.78 & Agree \\
\hline 7 & $\begin{array}{l}\text { Words with initial consonant clusters are difficult for students to pronounce. For instance, spray, } \\
\text { crystal, skewer, sclerosis and spirit }\end{array}$ & 999 & 3.60 & 0.48 & Agree \\
\hline 8 & $\begin{array}{l}\text { Words with end consonant clusters such as pinched, tasked, scuplpts, twelfths are difficult to } \\
\text { be pronounced. }\end{array}$ & 999 & 3.13 & 0.95 & Agree \\
\hline 9 & $\begin{array}{l}\text { Words with /r/ sound in a cluster of words are often pronounced as } / \mathbf{I} / . \text { Examples: scrub for } \\
\text { sclub, cream for cleam, scream for sleam. }\end{array}$ & 999 & 3.38 & 0.71 & Agree \\
\hline 10 & $\begin{array}{l}\text { Students often mistake silent letters with consonant clusters. For examples: (w) restle, of (t)en, } \\
\text { (p)sychology, su(btele }\end{array}$ & 999 & 3.86 & 0.33 & Agree \\
\hline 11 & 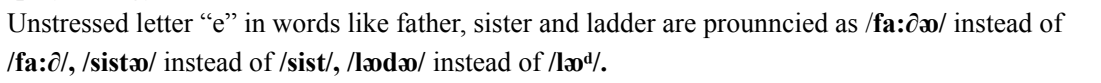 & 999 & 3.20 & 0.40 & Agree \\
\hline 12 & $\begin{array}{l}\text { Students mispronounce about /bout/ as /abbaut/ rot knowing that the ' } a \text { ' in 'about' is } \\
\text { unstressed. }\end{array}$ & 999 & 3.34 & 1.00 & Agree \\
\hline 13 & $\begin{array}{l}\text { Students also mispronounce husband } / \mathbf{h} \wedge \mathbf{z b n d} \text { as } / \mathbf{h} \wedge \mathbf{z b ə o n d} / \text { rot knowing that the ' } a \text { ' in } \\
\text { 'husband' is unstressed. }\end{array}$ & 999 & 3.39 & 0.61 & Agree \\
\hline 14 & $\begin{array}{l}\text { Students also mispronounce teacher /ti:t } \mathbf{f} / \text { as /ti: } \int \mathbf{z o} / \text { and knowing that the ' } \mathrm{e} \text { ' in 'teacher' is } \\
\text { unstressed. }\end{array}$ & 999 & 3.13 & 0.80 & Agree \\
\hline
\end{tabular}

Table 1 indicates that all the items received positive response, that is, they are above the decision point of 2.50 on the aspects of pronunciation that are considered problematic. The least item on the table is 2.79 which is the item number 5 while item number 10 has the highest score of 3.86 .

The mean responses indicate that consonant and vowel phonemes, syllabic consonants, consonant cluster, unstressed vowel, stress timing and among others are the aspects of pronunciation that are considered problematic among the students' studied as stated. 
Table 2. Mean ratings of the responses on the pronunciation problems in the Learning of English Grammar among the students' based on gender

\begin{tabular}{|c|c|c|c|c|c|c|c|c|c|}
\hline \multirow[t]{2}{*}{$\mathbf{S} / \mathbf{N}$} & \multirow[t]{2}{*}{ Item Statements } & \multicolumn{4}{|c|}{ Female } & \multicolumn{4}{|c|}{ Male } \\
\hline & & $\mathbf{N}$ & $\mathbf{X}$ & SD & Decision & $\mathbf{N}$ & $\mathbf{X}$ & SD & Decision \\
\hline 1. & $\begin{array}{l}\text { Students mispronounce consonant phoneme letter } / \theta / \text { for } / \mathrm{t} / \text {. } \\
\text { Examples: thank for tank, thick for tick }\end{array}$ & 549 & 3.80 & 0.39 & Agree & 450 & 3.80 & 0.39 & Agree \\
\hline 2 & $\begin{array}{l}\text { Students mispronounce consonant phoneme letter } / \mathrm{t} / \text { for } / \mathrm{n} / \text {. } \\
\text { Example: learning for nearing, land for nand, law for naw }\end{array}$ & 549 & 3.40 & 0.60 & Agree & 450 & 3.40 & 0.60 & Agree \\
\hline 3 & $\begin{array}{l}\text { Students mispronounce consonant phoneme letter } / 3: \text { for } /: / \\
\text { Examples: burn for born, turn for torn, curd for cord, word } \\
\text { for ward. }\end{array}$ & 549 & 3.33 & 0.78 & Agree & 450 & 3.33 & 0.78 & Agree \\
\hline 4 & $\begin{array}{l}\text { Students also mispronounce the vowel phoneme / / for } / \mathfrak{2} / \text {. } \\
\text { Example but for hut, cut for cot, cut for cop. }\end{array}$ & 549 & 3.34 & 0.86 & Agree & 450 & 3.34 & 0.86 & Agree \\
\hline 5 & $\begin{array}{l}\text { Students often use a vowel with a syllabic consonant } / 1 / \text {. Instead } \\
\text { of kettle } / \mathbf{k e t l} / \text {, pronounce } / \mathbf{b} \boldsymbol{b} \text { tle/. }\end{array}$ & 549 & 2.79 & 0.90 & Agree & 450 & 2.79 & 0.90 & Agree \\
\hline 6 & $\begin{array}{l}\text { Students use a vowel with a syllabic consonant /n/. Instead of } \\
\text { garden /ga:dn/they pronounce/ga:din/ and instead of bitten } \\
\text { /bitn/ they pronounce /bitin/. }\end{array}$ & 549 & 3.33 & 0.78 & Agree & 450 & 3.33 & 0.78 & Agree \\
\hline 7 & $\begin{array}{l}\text { Words with initial consonant clusters are difficult for students to } \\
\text { pronounce. For instance, spray, crystal, skewer, sclerosis and } \\
\text { spirit }\end{array}$ & 549 & 3.60 & 0.48 & Agree & 450 & 3.60 & 0.48 & Agree \\
\hline 8 & $\begin{array}{l}\text { Words with end consonant clusters such as pinched, tasked, } \\
\text { sculpts, twelfths are difficult to be pronounced }\end{array}$ & 549 & 3.13 & 0.95 & Agree & 450 & 3.13 & 0.95 & Agree \\
\hline 9 & $\begin{array}{l}\text { Words with /r/ sound in a cluster of words are often pronounced } \\
\text { as /l/. Examples: scrub for sclub, cream for cleam, scream for } \\
\text { sleam. }\end{array}$ & 549 & 3.38 & 0.71 & Agree & 450 & 3.38 & 0.71 & Agree \\
\hline 10 & $\begin{array}{l}\text { Students often mistake silent letters with consonant clusters. For } \\
\text { examples: (w) restle, of(t)en, (p)sychology, su(b)tele }\end{array}$ & 549 & 3.86 & 0.33 & Agree & 450 & 3.86 & 0.33 & Agree \\
\hline 11 & 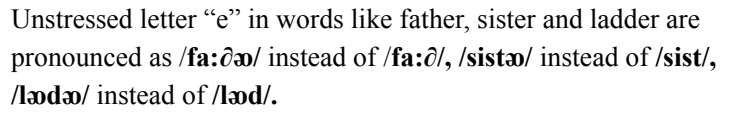 & 549 & 3.20 & 0.40 & Agree & 450 & 3.20 & 0.40 & Agree \\
\hline 12 & $\begin{array}{l}\text { Students mispronounce about /bout/ as /obaut/ rot knowing } \\
\text { that the 'a' in 'about' is unstressed. }\end{array}$ & 549 & 3.34 & 1.00 & Agree & 450 & 3.34 & 1.00 & Agree \\
\hline 13 & $\begin{array}{l}\text { Students also mispronounce husband } / \mathbf{h} \wedge \mathbf{z b n d} / \text { as } / \mathbf{h} \wedge \mathbf{z b ə o n d} / \\
\text { rot knowing that the 'a' in 'husband' is unstressed. }\end{array}$ & 549 & 3.39 & 0.61 & Agree & 450 & 3.39 & 0.61 & Agree \\
\hline 14 & $\begin{array}{l}\text { Students also mispronounce teacher / } \mathbf{t i : t} \mathbf{t} / \text { as / } \mathbf{t i}: \int \boldsymbol{\jmath} / \text { and } \\
\text { knowing that the 'e' in 'teacher' is unstressed. }\end{array}$ & 549 & 3.13 & 0.80 & Agree & 450 & 3.13 & 0.80 & Agree \\
\hline
\end{tabular}

The data on Table 2 indicate that items 1 to 14 received positive responses with mean scores above 2.5 which is the based point for acceptance. The least item for male is item 5 which has the mean score of 2.78 while the highest item for male is item 10 which has a mean score of 3.86. Coincidentally for female responses, the least item is also item 5 which has the mean score of 2.80 and the highest mean score of females is also item 10 which has the mean score of 3.80. All the respondents had the mean responses above the decision point in all the 14 items on influence of gender on pronunciation problems in the learning of English grammar among the students' studied. 
Table 3. Mean ratings of the response on the management strategies that can be used to control pronunciation problems among the students' studied

\begin{tabular}{|c|c|c|c|c|c|}
\hline $\mathbf{S} / \mathbf{N}$ & Item Statements & $\mathbf{N}$ & $\mathbf{X}$ & SD & Decision \\
\hline 1 & $\begin{array}{l}\text { Teachers' emphasis on the problematic areas of pronunciation such as consonant and vowel } \\
\text { phonemes. }\end{array}$ & 999 & 3.46 & 0.49 & Agree \\
\hline 2 & Constant practice on the part of the students & 999 & 3.40 & 0.49 & Agree \\
\hline 3 & Teachers' knowledge of Oral English & 999 & 3.46 & 0.61 & Agree \\
\hline 4 & Building of language laboratories in educational institutions. & 999 & 3.34 & 0.69 & Agree \\
\hline 5 & Teachers' use of compact disks on pronunciation & 999 & 3.33 & 0.78 & Agree \\
\hline 7 & Students' access to compact disks on pronunciation & 999 & 3.21 & 0.82 & Agree \\
\hline 8 & Students' access to tapes on pronunciation & 999 & 3.33 & 0.93 & Agree \\
\hline 9 & Listening to radio stations & 999 & 3.13 & 0.80 & Agree \\
\hline 10 & Learning and relearning of syllabic consonant, consonant cluster, and unstressed vowels. & 999 & 3.13 & 0.72 & Agree \\
\hline 11 & Using pronunciation dictionaries & 999 & 3.39 & 0.48 & Agree \\
\hline
\end{tabular}

Data on Table 3 reveal that items 15 to 25 received positive responses. Items 23 and 24 had the least score of 3.13 respectively while the items 15,17 and 20 had the highest mean score of 3.46 . The respondents had the mean responses above the decision point of 2.50 in the 11 items on the management strategies that can be used to control pronunciation problems.

This indicates that teachers'/facilitators emphasis on the problematic areas of pronunciation such as consonant and vowel phonemes, syllabic consonants, consonant cluster, unstressed vowels and stress timing, constant practice on the part of the students, teachers' knowledge of Oral English, building of language laboratories in educational institutions, teachers' use of compact disks on pronunciation, teachers' use of tapes on pronunciation, students' access to compact disks on pronunciation, students' access to tapes on pronunciation, listening to radio stations, listening to the native speaker of the English language and using pronunciation dictionaries are the management strategies that can be used to improve pronunciation problems.

Table 4. The t-test statistical analysis of the significant difference between the mean rating of male and female students on the pronunciation problems of students

\begin{tabular}{lllllllll}
\hline Gender & $\mathbf{N}$ & Mean & Std. deviation & Df & t- & t-critical & Decision & Remark \\
\hline Male & 450 & 3.36 & .21 & 997 & .55 & 1.96 & Accepted & NS \\
Female & 549 & 3.39 & .21 & & & & & \\
\hline
\end{tabular}

Table 4 above indicates that at 0.05 percent level of significance and 997 degree of freedom, the calculated 0.58 is less than the critical $t$ of 1.96 . The $\mathrm{H}_{1}$ is upheld. The researchers therefore, concluded that views of male and female students on the pronunciation problems do not differ significantly.

\section{Discussion}

From the findings obtained using the items in research question one, it is obvious that consonant and vowel phonemes, syllabic consonants, consonant cluster, unstressed vowel and stress timing are the aspects of pronunciation that are considered problematic in the learning of English grammar. This is in line with what Anyachonkeya and Izuagba (1999) stated that the proficiency in spoken English can be impaired by some problematic areas of pronunciation such as consonant and vowel and stress timing. Onuigbo (2006) also agrees with the above that consonant cluster also poses difficulty to the learners of English language. For him, such difficulty results in cluster of two or three consonants without an intervening vowel.

From the results of the findings, gender has no influence on the pronunciation problems among first year university students in the learning of English grammar. This finding is not in agreement with assertion Enete's (2008) that gender plays a functional role in the teaching of Oral English in favor of the females.

The findings from the research question three suggest that teachers' emphasis on the problematic areas of pronunciation such as consonant and vowel phonemes, syllabic consonants, consonant cluster, unstressed vowel and stress timing, constant practice on the part of the students, teachers' knowledge of Oral English, building of language laboratories in schools, teachers' use of compact disks on pronunciation, teachers' use of tapes on pronunciation. Others include students' access to compact disks on pronunciation, students' access to tapes on pronunciation, listening to radio stations, listening to the native speaker of the English language and using 
pronunciation dictionaries are the management strategies that can be used to control pronunciation problems. Eyisis (2002) supports this when she found out that accelerated improvement in the pronunciation of English words is dependent on effective listening and continuous practice. This is also in line with what Mbah's (2004) findings that English language teachers/facilitators need more special training in the phonetics of English language. Also, the findings of this study support Roach (2003) idea of building language laboratories in educational institutions. For Roach, experimental phonetics has been an important part of phonetics for most of the twentieth century, and experimental work in phonetics laboratories has produced many important discoveries about how speech is produced and perceived. Also, they support Anyachonkeya and Izuagba's (1999) findings that teachers of Oral English are to teach the students those areas that are problematic.

\section{Conclusion}

From the findings of the study, the following conclusions were drawn as the aspects of pronunciation that are considered problematic in the learning of English grammar. These problematic areas are consonant and vowel phonemes, syllabic consonants, consonant cluster, unstressed and stress timing. However, the study also reveals that gender has no influence on the pronunciation problems in the learning of English grammar. The study also identifies shows some of the management strategies that can be used to control pronunciation problems-consonant and vowel phonemes, syllabic consonants, consonant cluster, unstressed vowels, teachers' use of compact disks on pronunciation, students' access of compact disks on pronunciation, using pronunciation dictionaries, among others.

\section{References}

Adesino, S. (1990). Educational Management. Enugu: Fourth Dimention Publishing Co. Ltd.

Adina, E. E., Ladipo, S., \& Abosi, C. O. (1991). Introduction to special education. Ibadan, Heinman Education Publisher.

Allen, B. P. (2002). Personality theories, development, growth, and diversity. London, Allyn and Bacon.

Anyachonkeya, N., \& Izuagba, A. C. (1999). A handbook of the English teaching and methodology Owerri. Nigeria: Hudsonjude.

Badura, A. (1977). Social learning theory. Engle-wood Cliffs, NJ: Pretice-Hall.

Baldeh, F. (1990). Better English language learning and teaching. Nsukka: Fulladu Publishing Company.

Boss, C. S., \& Vaughon, S. (2002). Strategies for teaching students with learning and behavior problems. Boston, Allyn \& Bacon.

Comrie, B. (2008). Language. Microsoft student with Encarta premium DVD, Enete AN 2008. "Language". Microsoft student with Encarta premium DVD, 2008.

Eyisi, J. (2002). Oral English for successful performance. Awka, SCOA Heritage Systems.

Ezurike-Nwadigo, N. (2008). Zenith Indepth English for Wasscs, Fce, Neco, Jamb and Students of Tertiary Institutions. Jos, YA-BYANGS Publishers.

Hughes, M., Kroehler, C. J., \& Zanden, J. W. V. (1999). Sociology: The core. USA, McGraw- Hill.

Mangal, S. K. (2010). Educating exceptional children. An introduction to special education. New Delhi, PHI Learning Private Limited.

Mba, B. M., \& Mba, E. E. (2000). Topics in phonetics and phonology contribution from Igbo. Nsukka, AP: Express Publishers.

Mbah, E. (2004). Problems Associated with the learning of Oral English. PGDE Thesis, UNN.

Myers, D. G. (2002). Exploring psychology. New York: McGraw-Hill.

Ngwoke, D. U. (2010). School learning theories and application. Enugu: Immaculate publication Limited.

Nnamani, B. I. (2008). Factors Affecting. Effective and learning or oral English. PGDE Thesis, UNN.

Nworgu, B. G. (2015). Educational Research: Basic Issues and Methodology. Enugu: University Trust Publishers.

Okoye, N. N. (2001). Psychology of human learning and development. Awka: Erudition Publishers.

Onuigbo, S. (2006). Oral English for schools and colleges. Onitsha: Africana First Publishers Ltd.

Osuala, E. C., \& Okeke, A. U. (2006). Administrative office management. Enugu: Cheston Agency Ltd. 
Otagburuagu, E. J. (1997). Teaching and writing skill in the English language: theories, issues and practice. Onitsha, Cape Publishers International Ltd.

Roach, P. (2003). English phonetics and phonology: A self-contained, comprehensive pronunciation course. UK: Cambridge University Press.

Umeano, E. C. (1999). A First course in educational psychology made brief. Enugu: Magnet Business Enterprises.

Wilkins, D. A. (1979). Second language learning and teaching. London: Edward Arnold.

\section{Copyrights}

Copyright for this article is retained by the author, with first publication rights granted to the journal.

This is an open-access article distributed under the terms and conditions of the Creative Commons Attribution license (http://creativecommons.org/licenses/by/4.0/). 